\title{
KCNQ1 Opposite Strand/Antisense Transcript 1
}

National Cancer Institute

\section{Source}

National Cancer Institute. KCNQ1 Opposite Strand/Antisense Transcript 1. NCI

Thesaurus. Code C114318.

KCNQ1 opposite strand/antisense transcript 1 ( 92 kb) is encoded by the human KCNQ1OT1 gene. This non-coding RNA plays a role in epigenetic processes. 